Finally, in giving explanations, statistics, and comparative results, the author appears to be under the impression that if he makes a statement sufficiently frequently it must ultimately be accepted by any reasonable individual. May we make the suggestion that when the larger work appears it should contain more accurate accounts of the really fundamental differences between Spengler's work and that of his contemporaries, that full descriptions of all special methods be given, and that, in order to make room for many things that are here taken for granted, much irrelevant matter and repetition should be omitted?

\section{SCIENCE OF TANNING.}

The Puering, Bating, and Drenching of Skins. By J. T. Wood. Pp. $x v+3$ oo. (London: E. and F. N. Spon, Ltd. ; New York : Spon and Chamberlain, rgr2.) Price r2s. 6d. net.

THE author in his preface claims that this volume is merely a collection of notes he has made during the past twenty years on the practical and scientific aspect of the puering, bating, and drenching of skins. "Puering" and "bating" are two processes commonly used in the manufacture of light and fancy leather from various skins. They consist of steeping the skins prior to tanning in a fermenting solution of excrement-in the case of "puering," dog excrement is used; in "bating," hen or pigeon manure. Subsequent to either of these processes the skins are "drenched," in which process they are placed in a fermenting solution of bran, which, by reason of its acid nature, swells the skins prior to tanning. The original of the words puering and bating is French-puer, to stink; bête, animal. The aim of scientific technologists is to substitute these two disgusting processes by cleaner materials which can be scientifically controlled. Puering and bating of skins reduce them in thickness, take out the lime and grease, and make them soft and velvety. Mr. Wood has put together his notes upon these subjects in such a way as to make this volume indispensable both to leather trades chemists and to those who wish specially to study the subject. It is, in short, a text-book bringing together in handy form all that has been done and all that is known of this, one of the most complicated processes in connection with leather manufacture.

In the first chapter the author gives an outline of the practical processcs of puering and bating. This chapter deals more with the practical side, although scientific data are given in the form of analyses and analytical results connected with practical trials. The author describes also the use of Sand's electrometric apparatus for the controlling of puer and bate liquors.

In subsequent chapters the author deals with the physics and chemistry of bating. These chapters are probably beyond the ken of the average leather manufacturer, as the author deals with the measurement of the hydrogen-ion concentration, the conductivity of puer liquors, and also describes a new apparatus for measuring the degree of fall. ing, illustrating the work of the instrument by curves.

Chapter iv. deals with the bacteriology of the bate, and here the author excels and gives a fund of information which will be most valuable to all branches of the leather industry. The author gives microphotographs of many of the active bacteria of the puer and bate, some of which have been isolated and named by himself.

The remaining chapters contain a number of Mr. Wood's original papers which have been contributed to various learned societies from time to time. A further chapter deals with artificial bates which from time to time have been suggested, some of which are being used with satisfactory results. Lastly, Mr. Wood has collected in convenient form a résumé of all the patents and the bibliography of the subject.

A special portion of the book deals with drenching, one of the subsequent processes to puering or bating, and one which must be treated quite apart. Various analyses and bacteriological investigations are fully described.

The book is one which all interested in the scientific side of the leather trade must possess. To the practical leather manufacturer the book may be a disappointment, as the author does not deal with the old practical difficulties.

Mr. Wood describes his book in the concluding chapter as follows :-

" Limited in extent, imperfect in execution, and in parts only suggestive in character, this little book may perhaps serve as a foundation on which students of the science of tanning may raise the superstructure of their own experience and eventually perfect the processes touched upon, so that the use of such filthy materials may be entirely avoided."

This is another example of Mr. Wood's modesty. The book goes further than he claims. It is indeed refreshing to find someone brave enough to publish the results of his years of study of this, one of the least understood and most complicated processes connected with the manufacture of leather.

Needless to add, the printing, illustrations, and the general get-up of the book leave nothing to be desired.
J. G. P.

NO. 2240 , VOL. 90] 